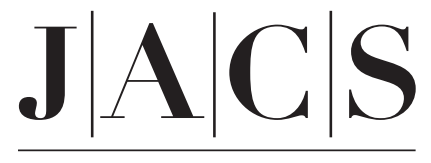

A R T I C L E S

Published on Web 11/30/2007

\title{
Protein Nanopores with Covalently Attached Molecular Adapters
}

\author{
Hai-Chen Wu, Yann Astier, Giovanni Maglia, Ellina Mikhailova, and Hagan Bayley* \\ Department of Chemistry, University of Oxford, Oxford, OX1 3TA, United Kingdom
}

Received August 21, 2007; E-mail: hagan.bayley@chem.ox.ac.uk

\begin{abstract}
Molecular adapters are crucial for the stochastic sensing of organic analytes with $\alpha$-hemolysin $(\alpha \mathrm{HL})$ protein nanopores when direct interactions between analytes and the pore cannot readily be arranged by conventional protein engineering. In our earlier studies, cyclodextrin adapters were lodged noncovalently within the lumen of the $\alpha \mathrm{HL}$ pore. In the present work, we have realized the controlled covalent attachment of a $\beta$-cyclodextrin $(\beta C D)$ adapter in the two possible molecular orientations inside $\alpha \mathrm{HL}$ pores prepared by genetic engineering. There are two advantages to such a covalent system. First, the adapter cannot dissociate, which means there are no gaps during stochastic detection, a crucial advance for single-molecule exonuclease DNA sequencing where the continuous presence of a molecular adapter will be essential for reading individual nucleotides. Second, the ability to orient the adapter allows analytes to bind through only one of the two entrances to the $\beta C D$ cavity. We demonstrate that the covalently attached adapters can be used to alter the ion selectivity of the $\alpha \mathrm{HL}$ pore, examine binding events at elevated temperatures, and detect analytes with prolonged dwell times.
\end{abstract}

\section{Introduction}

Stochastic detection is an approach to sensing that relies on the observation of individual binding events between analyte molecules and a receptor. Stochastic sensors can be created by placing a single pore of nanometer dimensions in an insulating membrane and measuring voltage-driven ionic transport through the pore in the presence of analyte molecules. The frequency of occurrence of fluctuations in the current reveals the concentration of an analyte that binds within the pore. The identity of an analyte is revealed through its distinctive current signature, notably the duration and extent of current block. ${ }^{1,2}$

Engineered versions of the bacterial pore-forming toxin $\alpha$-hemolysin $(\alpha \mathrm{HL})$ have been used in our group for stochastic sensing of many classes of molecules. ${ }^{2-11}$ In the course of this work, we found that attempts to engineer $\alpha \mathrm{HL}$ to bind small organic analytes directly can prove taxing, with rare examples of success. ${ }^{7}$ Fortunately, a different strategy was discovered,

* To whom correspondence should be addressed. Tel: +44-1865 285101. Fax: +44-1865 275708 .

(1) Braha, O.; Walker, B.; Cheley, S.; Kasianowicz, J. J.; Song, L.; Gouaux, J. E.; Bayley, H. Chem. Biol. 1997, 4, 497-505.

(2) Bayley, H.; Cremer, P. S. Nature 2001, 413, 226-230.

(3) Shin, S.-H.; Luchian, T.; Cheley, S.; Braha, O.; Bayley, H. Angew. Chem., Int. Ed. 2002, 41, 3707-3709.

(4) Cheley, S.; Gu, L.-Q.; Bayley, H. Chem. Biol. 2002, 9, 829-838.

(5) Howorka, S.; Nam, J.; Bayley, H.; Kahne, D. Angew. Chem., Int. Ed. 2004 $43,842-846$.

(6) Xie, H.; Braha, O.; Gu, L.-Q.; Cheley, S.; Bayley, H. Chem. Biol. 2005, $12,109-120$

(7) Guan, X.; Gu, L.-Q.; Cheley, S.; Braha, O.; Bayley, H. ChemBioChem 2005, 6, 1875-1881.

(8) Braha, O.; Webb, J.; Gu, L.-Q.; Kim, K.; Bayley, H. ChemPhysChem 2005 6, 889-892.

(9) Kang, X. F.; Cheley, S.; Guan, X.; Bayley, H. J. Am. Chem. Soc. 2006, $128,10684-10685$.

(10) Cheley, S.; Xie, H.; Bayley, H. ChemBioChem 2006, 7, 1923-1927.

(11) Astier, Y.; Braha, O.; Bayley, H. J. Am. Chem. Soc. 2006, 128, 1705-10.

16142 - J. AM. CHEM. SOC. 2007, 129, 16142-16148 which utilized noncovalently attached molecular adapters, notably cyclodextrins, ${ }^{12}$ but also cyclic peptides ${ }^{13}$ and cucurbiturils. ${ }^{8}$ Cyclodextrins become lodged in the $\alpha \mathrm{HL}$ pore and produce a substantial but incomplete channel block. Organic analytes, which bind within the hydrophobic interiors of cyclodextrins, augment this block allowing analyte detection. ${ }^{9,11,12,14,15}$ It is even possible to distinguish the enantiomers of drug molecules by this powerful approach. ${ }^{9}$

For most purposes, sensing with molecular adapters would be enhanced if the adapter did not every so often dissociate from the pore, leaving the latter unable to bind and register analyte molecules. The situation can be improved by using pores that have been engineered to bind cyclodextrins for long periods of time. For example, the homoheptameric mutants $(\mathrm{M} 113 \mathrm{~N})_{7}$ and $(\mathrm{M} 113 \mathrm{~F})_{7}$ bind $\beta$-cyclodextrin $(\beta \mathrm{CD})$ for $10^{4}$ times longer than the wild-type (WT) protein. ${ }^{14-16}$ In the present work, we have accomplished the technically difficult task of attaching $\beta \mathrm{CD}$ covalently within the $\alpha \mathrm{HL}$ pore in stable orientations by using a bifunctional linker. The mutations at position 113 were used to position the adapters for covalent bonding and to stabilize them within the lumen of the pore after reaction. Attachment was accomplished through cysteine residues placed at positions which, based on structural data and molecular modeling, would accommodate a linker of specified dimensions. Covalent attachment has two important outcomes. First, the adapter cannot dissociate from the nanopore. Second, the

(12) Gu, L.-Q.; Braha, O.; Conlan, S.; Cheley, S.; Bayley, H. Nature 1999, 398, 686-690.

(13) Sanchez-Quesada, J.; Ghadiri, M. R.; Bayley, H.; Braha, O. J. Am. Chem. Soc. 2000, 122, 11758-11766.

(14) Gu, L.-Q.; Cheley, S.; Bayley, H. Science 2001, 291, 636-640.

(15) Kang, X.; Gu, L.-Q.; Cheley, S.; Bayley, H. Angew. Chem., Int. Ed. 2005 44, 1495-1499.

(16) Gu, L.-Q.; Cheley, S.; Bayley, H. J. Gen. Physiol. 2001, 118, 481-494. 

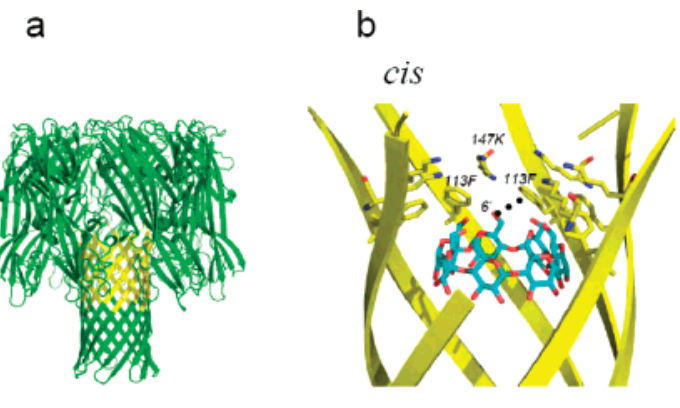

C

trans

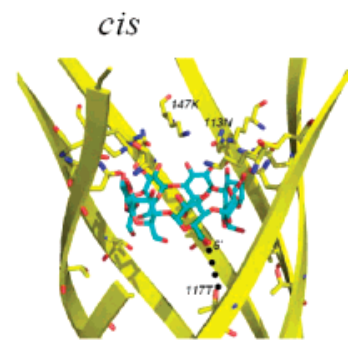

trans

Figure 1. X-ray structures of $(\mathrm{M} 113 \mathrm{~F})_{7} \cdot \beta \mathrm{CD}$ and $(\mathrm{M} 113 \mathrm{~N})_{7} \cdot \beta \mathrm{CD}$ generated from the pdb files (Montoya and Gouaux, unpublished). (a) Side view of the $\alpha \mathrm{HL}$ pore with amino acids $108-120$ and $138-150$ highlighted in yellow. (b) (M113F) $)_{7} \cdot \beta \mathrm{CD}$. Amino acids $108-120$ of $\alpha \mathrm{HL}$ are depicted in yellow, and $\beta \mathrm{CD}$ is shown in blue sticks. The side chains of Phe-113 and Lys-147 are also shown in stick form. The distance between the $\mathrm{O}$ atom of a primary hydroxyl of $\beta \mathrm{CD}$ and the center of the nearest phenyl ring of Phe-113 is about $6.5 \AA$ (dotted line). (c) (M113N) $)_{7} \cdot \beta \mathrm{CD}$. Amino acids $108-120$ of $\alpha \mathrm{HL}$ are depicted in yellow, and $\beta \mathrm{CD}$ is shown in blue sticks. The side chains of Asn-113, Lys-147, and Thr-117 are also shown in stick form. The distance between the O atom of a primary hydroxyl of $\beta \mathrm{CD}$ and the nearest $\mathrm{O}$ atom of Thr-117 is about $6.0 \AA$ (dotted line).

orientation of the cyclodextrin can be controlled with either the primary hydroxyls or the secondary hydroxyls facing the trans entrance of the pore.

\section{Results and Discussion}

Design of the Linker and Derivatization of Engineered $\alpha$ HL Pores with $\beta$ CD-PDP. The X-ray structures of $(\mathrm{M} 113 \mathrm{~F})_{7}{ }^{\bullet}$ $\beta \mathrm{CD}$ and $(\mathrm{M} 113 \mathrm{~N})_{7} \cdot \beta \mathrm{CD}$ (Figure 1 , Montoya and Gouaux, unpublished) reveal the positions of noncovalently bound $\beta \mathrm{CD}$ within the $\beta$ barrel of the $\alpha \mathrm{HL}$ pore. In $(\mathrm{M} 113 \mathrm{~F})_{7} \cdot \beta \mathrm{CD}$, the seven phenyl rings of Phe-113 take part in hydrophobic interactions with the seven primary 6-hydroxylmethyl groups of $\beta \mathrm{CD}$, resulting in a specific orientation of the $\beta \mathrm{CD}$ within the pore, in which the primary hydroxyls point toward the cis mouth (Figure $1 \mathrm{~b})$. In contrast, in $(\mathrm{M} 113 \mathrm{~N})_{7} \cdot \beta \mathrm{CD}$, the seven amide groups of Asn-113 and the $\epsilon$-amino groups of Lys-147 are, respectively, within hydrogen-bonding distance of the seven 2 - and the seven 3-secondary hydroxyl groups of $\beta \mathrm{CD}$. In this orientation, the primary hydroxyl groups of $\beta \mathrm{CD}$ point toward the trans entrance of the pore (Figure 1c).

By molecular modeling, we identified suitable positions in the lumen of the $\alpha \mathrm{HL}$ barrel at which to attach $\beta \mathrm{CD}$. In $(\mathrm{M} 113 \mathrm{~F})_{7} \cdot \beta \mathrm{CD}$, the distance between the center of a phenyl ring of Phe-113 and the nearest $\mathrm{O}$ atom of a primary hydroxyl group of $\beta \mathrm{CD}$ is $6.5 \pm 0.5 \AA$ (average of the seven positions) (Figure $1 \mathrm{~b})$. In $(\mathrm{M} 113 \mathrm{~N})_{7} \cdot \beta \mathrm{CD}$, the distance between the $\mathrm{O}$ atom of a primary hydroxyl group of $\beta \mathrm{CD}$ and the closest $\mathrm{O}$ atom of Thr-117 is on average $6.0 \pm 0.5 \AA$ (Figure 1c). We chose a bifunctional crosslinker succinimidyl 3-(2-pyridyldithio)propionate (SPDP) to link 6-monodeoxy-6-monoamino- $\beta$-cyclodextrin $\left(\mathrm{am}_{1} \beta \mathrm{CD}\right.$, in which a single primary hydroxyl group of $\beta \mathrm{CD}$ is substituted with an amino group) to a cysteine residue at position-113 or position-117. We first coupled $\mathrm{am}_{1} \beta \mathrm{CD}$ with SPDP to form 6-monodeoxy-6-[3-(2-pyridyldithio)propionyl]monoamino- $\beta$-cyclodextrin ( $\beta$ CD-PDP) (Figure 2$)$. In $\beta \mathrm{CD}$ PDP, the pyridyl disulfide at the end of the linker can be attacked by the free thiol of a cysteine residue in the $\alpha \mathrm{HL}$ pore to form a disulfide bond. The length of the linker was measured by building $\beta \mathrm{CD}$-PDP in PyMol; the distance between the $\mathrm{N}$ atom in the amide bond of $\operatorname{am}_{1} \beta \mathrm{CD}$ and the pyridyl $\mathrm{S}$ atom is $\sim 7.0$ $\AA$ in an extended conformation. Therefore, the linker is slightly longer than required for linking $\mathrm{am}_{1} \beta \mathrm{CD}$ to a cysteine at position-113 with the $\beta \mathrm{CD}$ in the orientation found in $(\mathrm{M} 113 \mathrm{~F})_{7}$
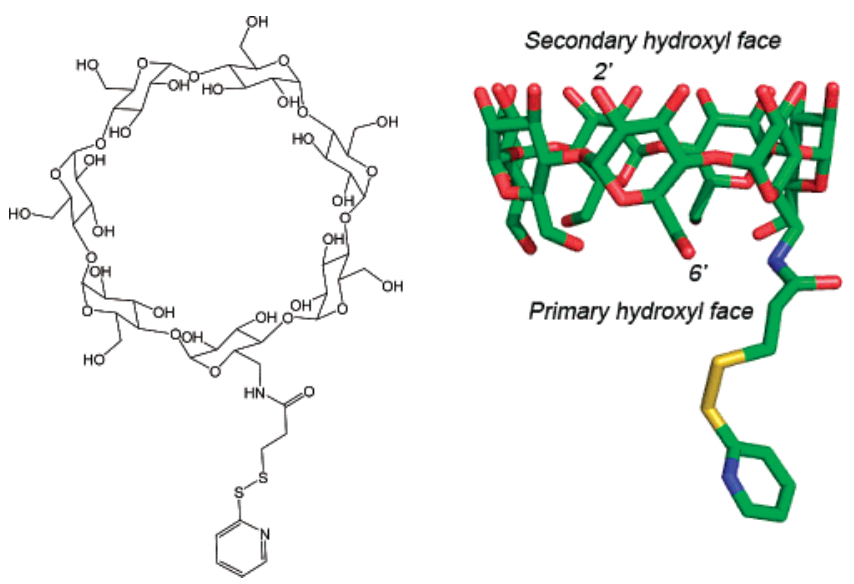

Figure 2. Chemical structure and stick representation of $\beta \mathrm{CD}-\mathrm{PDP}$. The molecule was drawn in ChemDraw 3D and then rendered in PyMOL.

or to a cysteine at position-117 with the $\beta \mathrm{CD}$ in the orientation found in $(\mathrm{M} 113 \mathrm{~N})_{7}$.

On the basis of these modeling studies, a heteroheptameric $\alpha$ HL pore (M113F) 6 (M113C-D8RL2) 1 was engineered with six phenylalanine residues at position-113 and a single cysteine at the seventh position. The cysteine residue in the M113C subunit was designed to react with the pyridyl disulfide of $\beta C D-P D P$ presented from the trans side of the bilayer in such a way that the primary hydroxyls of the cyclodextrin would remain in the proximity of the six Phe residues of the M113F subunits. After reaction, $\beta C D$ would be anchored inside the $\alpha \mathrm{HL}$ pore as a permanent molecular adapter. In another construct, we placed a cysteine residue at position-117 in the engineered pore (M113N)6(T117C-D8RL3) . This pore was designed to react with $\beta \mathrm{CD}$-PDP while maintaining the stabilizing interactions of the secondary hydroxyls hydrogen bonded to residues Asn113 and Lys-147 in the M113N subunits.

We portrayed the desired covalent complexes $(\mathrm{M} 113 \mathrm{~F})_{6}$ - $^{-}$ $(\mathrm{M} 113 \mathrm{C}-\mathrm{D} 8 \mathrm{RL} 2)_{1}-\beta \mathrm{CD}$ and $(\mathrm{M} 113 \mathrm{~N})_{6}(\mathrm{~T} 117 \mathrm{C}-\mathrm{D} 8 \mathrm{RL} 3)_{1}-\beta \mathrm{CD}$ in PyMOL. In (M113F) ${ }_{6}(\mathrm{M} 113 \mathrm{C}-\mathrm{D} 8 \mathrm{RL} 2)_{1}-\beta \mathrm{CD}$, the distance between the amide $\mathrm{N}$ atom of $\mathrm{am}_{1} \beta \mathrm{CD}$ and the $\mathrm{S}$ atom of the cysteine at position 113 is $5.6 \AA$ (Figures 3c, S1). In (M113N)6(T117C-D8RL3) ${ }_{1}-\beta \mathrm{CD}$, the distance between the amide $\mathrm{N}$ atom of $\mathrm{am}_{1} \beta \mathrm{CD}$ and the $\mathrm{S}$ of cysteine at position 117 is $6.2 \AA$ (Figures $4 \mathrm{c}, \mathrm{S} 2$ ). These values are close to the corresponding measurements taken from the X-ray structures of the noncova- 

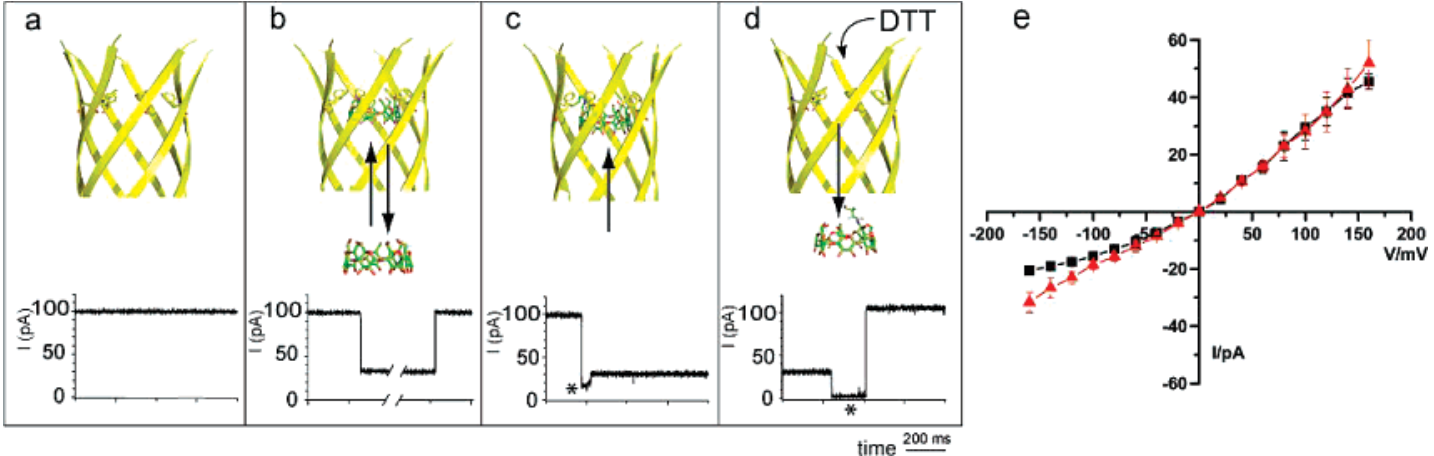

Figure 3. Comparison of the properties of the noncovalent complex $\alpha \mathrm{HL}(\mathrm{M} 113 \mathrm{~F})_{7} \cdot \beta \mathrm{CD}$ and the covalent adduct $\alpha \mathrm{HL}(\mathrm{M} 113 \mathrm{~F})_{6}(\mathrm{M} 113 \mathrm{C}-\mathrm{D} 8 \mathrm{RL} 2)_{1}-\beta \mathrm{CD}$. Each experiment was repeated at least six times. (a) Cartoon representation of amino acids $108-120$ of the mutant $\alpha \mathrm{HL}$ pore (M113F) 7 . Phe-113 residues are represented in stick form. Single-channel current trace from a $(\mathrm{M} 113 \mathrm{~F})_{7}$ pore in $25 \mathrm{mM}$ Tris $\cdot \mathrm{HCl}, \mathrm{pH} 8.0,1 \mathrm{M} \mathrm{KCl},+100 \mathrm{mV}$. (b) Cartoon representation of $\alpha \mathrm{HL}(\mathrm{M} 113 \mathrm{~F})_{7}$ with $\beta \mathrm{CD}$ bound as revealed by the $\mathrm{X}$-ray structure of $(\mathrm{M} 113 \mathrm{~F})_{7} \cdot \beta \mathrm{CD}$. The arrows indicate that $\beta \mathrm{CD}$ is free to move in and out of the pore. The current trace shows an initially unoccupied pore followed by the binding of $\beta \mathrm{CD}$ and its subsequent dissociation (mean $\tau_{\mathrm{off}}=316 \pm 62 \mathrm{~ms}$ ). (c) Cartoon representation of amino acids 108-120 of $\alpha \mathrm{HL}$ (M113F)6(M113C-D8RL2)1. Phe-113 residues are represented in stick form, and Cys-113 is colored in brown and also represented in sticks (an enlarged view of Figure 3c can be found in the Supporting Information as Figure S1a). The arrow indicates that when $\beta$ CD-PDP enters the pore the primary hydroxyls interact with the side chains of Phe-113, and Cys-113 reacts with the pyridyl disulfide of $\beta$ CD-PDP to form a disulfide bond. The current trace shows the current amplitude changes during the reaction. The transient state with $85 \%$ current block is marked (*). (d) Cleavage of (M113F) 6 (M113C-D8RL2) $1-\beta C D$ with dithiothreitol (DTT). The arrow indicates that the cyclodextrin derivative detaches from position113 after cleavage of the disulfide bond with DTT. The current trace shows the current amplitude changes during cleavage. The transient state with $98 \%$ current block is marked (*). (e) Single-channel $I-V$ curves for $(\mathrm{M} 113 \mathrm{~F})_{7} \cdot \beta \mathrm{CD}(\boldsymbol{\Delta})$ and $\alpha \mathrm{HL}(\mathrm{M} 113 \mathrm{~F})_{6}(\mathrm{M} 113 \mathrm{C}-\mathrm{D} 8 \mathrm{RL} 2)_{1}-\beta \mathrm{CD}(\boldsymbol{\square})$. Conditions: $25 \mathrm{mM}$ Tris $\cdot \mathrm{HCl}, \mathrm{pH} 8.0,1 \mathrm{M} \mathrm{KCl}$.
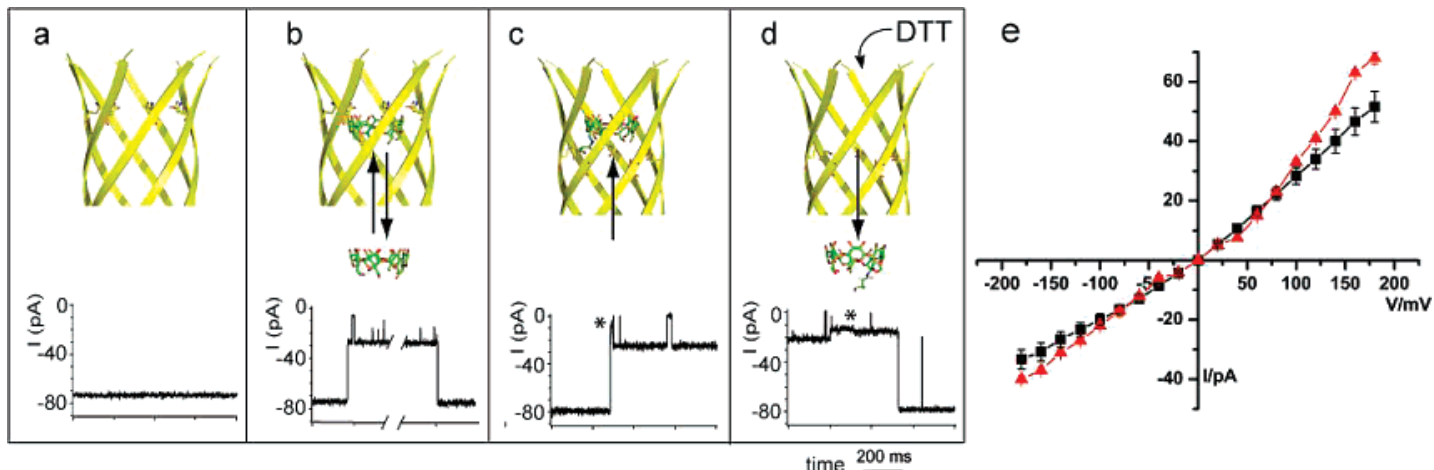

Figure 4. Comparison of the properties of the noncovalent complex $\alpha \mathrm{HL}$ (M113N) $)_{7}-\beta \mathrm{CD}$ and the covalent adduct $\alpha \mathrm{HL}$ (M113N) 6 (T117C-D8RL3) $\beta$ CD. Each experiment was repeated at least six times. (a) Cartoon representation of amino acids $108-120$ of the mutant $\alpha \mathrm{HL}$ pore (M113N) . Asn-113 residues are represented in stick form. Single-channel current trace from a $(\mathrm{M} 113 \mathrm{~N})_{7}$ pore in $25 \mathrm{mM}$ Tris $\cdot \mathrm{HCl}, \mathrm{pH} 8.0,1 \mathrm{M} \mathrm{KCl},-100 \mathrm{mV}$. (b) Cartoon representation of $\alpha \mathrm{HL}(\mathrm{M} 113 \mathrm{~N})_{7}$ with $\beta \mathrm{CD}$ bound as revealed by the X-ray structure of $(\mathrm{M} 113 \mathrm{~N})_{7} \cdot \beta \mathrm{CD}$. The arrows indicate that $\beta \mathrm{CD}$ is free to move in and out of the pore. The current trace shows an initially unoccupied pore followed by the binding of $\beta \mathrm{CD}$ and its subsequent dissociation (mean $\tau_{\text {off }}=10.7$ $\pm 1.5 \mathrm{~s})$. (c) Cartoon representation of amino acids $108-120$ of $\alpha \mathrm{HL}(\mathrm{M} 113 \mathrm{~N})_{6}(\mathrm{~T} 117 \mathrm{C}-\mathrm{D} 8 \mathrm{RL} 3)_{1}$. Asn-113 residues are represented in stick form, and Cys-117 is colored in brown and also represented in sticks (an enlarged view of Figure $4 \mathrm{c}$ can be found in the Supporting Information as Figure S1b). The arrow indicates that when $\beta \mathrm{CD}$-PDP enters the pore the secondary hydroxyls interact with the side chains of Asn- 113 , and Cys-117 can react with the pyridyl disulfide of $\beta \mathrm{CD}$-PDP to form a disulfide bond. The current trace shows the current amplitude change when the reaction takes place between Cys-117 and the pyridyl disulfide of $\beta$ CD-PDP. The transient state with $90 \%$ current block is marked (*). (d) Cleavage of (M113N)6(T117C-D8RL3) $1-\beta$ CD with DTT. The arrow indicates that the cyclodextrin derivative detaches from position-117 after cleavage of the disulfide bond. The current trace shows the current amplitude changes during cleavage. The transient state with $80 \%$ current block is marked $(*)$. (e) Single-channel $I-V$ curves for $(\mathrm{M} 113 \mathrm{~N})_{7} \cdot \beta \mathrm{CD}(\boldsymbol{\Delta})$ and $\alpha \mathrm{HL}(\mathrm{M} 113 \mathrm{~N})_{6}(\mathrm{~T} 117 \mathrm{C}-\mathrm{D} 8 \mathrm{RL} 3)_{1}-\beta \mathrm{CD}(\mathbf{\square})$. Conditions: $25 \mathrm{mM}$ Tris $\cdot \mathrm{HCl}, \mathrm{pH} 8.0,1 \mathrm{M} \mathrm{KCl}$.

lent complexes (see above) and confirm that the choice of the linker length is correct.

Electrical Characterization of (M113F) 6 (M113C-D8RL2) $)_{1}$ $\beta$ CD. When a single $(\mathrm{M} 113 \mathrm{~F})_{6}(\mathrm{M} 113 \mathrm{C}-\mathrm{D} 8 \mathrm{RL} 2)_{1}$ pore was introduced into a lipid bilayer from the cis chamber, we measured an ionic current of $98 \pm 5 \mathrm{pA}(+100 \mathrm{mV}, 25 \mathrm{mM}$ Tris $\cdot \mathrm{HCl}$, pH $8.0,1 \mathrm{M} \mathrm{KCl}, n=6$ ), which is very close to that of the $(\mathrm{WT})_{7}$ pore $(100 \pm 5 \mathrm{pA}, n=3)$ under the same conditions. To observe the reaction of $\beta \mathrm{CD}$-PDP with the pore, the reagent was added to the trans chamber and the potential was held at $+100 \mathrm{mV}$ (Figure 3). Two types of transient blocking events were observed, amounting to $70 \%$ (Figure 3b) and $98 \%$ (Figure S2, Supporting Information) of the total current. By contrast, when $\beta \mathrm{CD}$ interacts with $(\mathrm{M} 113 \mathrm{~F})_{7}$, only
$70 \%$ current blockades are observed. Therefore, the $70 \%$ block is most likely generated when $\beta \mathrm{CD}$-PDP binds within the pore with its primary hydroxyls interacting with the Phe-113 side chains and the linker protruding toward the cis side. The $98 \%$ block may occur when $\beta$ CD-PDP enters the pore with the pyridyl ring lodged inside the cavity of the cyclodextrin, thereby reducing the current flow. Eventually, after a period ranging from $5 \mathrm{~min}$ to $1 \mathrm{~h}$, the current level became permanently locked into a state of $70 \%$ block. This event was preceded by an $85 \%$ block that lasted for $48 \pm 7 \mathrm{~ms}(n=5)$ (Figures 3c, S2). No recovery of the current from the $70 \%$ blocked state to that of the unmodified pore was observed during a total recording period of $24 \mathrm{~h}$ (over 16 experiments). By comparison, the mean dwell time $\left(\tau_{\text {off }}\right)$ of $\beta \mathrm{CD}$ noncovalently bound to $(\mathrm{M} 113 \mathrm{~F})_{7}$ is 
$316 \pm 62 \mathrm{~ms}$ under the same conditions. The blocked state is presumed to represent the $\alpha \mathrm{HL}$ pore with $\beta \mathrm{CD}$ covalently attached through a disulfide bond at position 113 (Figures 3c, S1a). In keeping with this idea, the disulfide bond was cleaved after the addition of $2 \mathrm{mM}$ DTT to the cis chamber. During cleavage a transient intermediate state with a lifetime of $150 \pm$ $12 \mathrm{~ms}(n=5)$ and $98 \%$ current block was observed (Figure $3 \mathrm{~d})$. The $70 \%$ block in (M113F) $)_{6}(\mathrm{M} 113 \mathrm{C}-\mathrm{D} 8 \mathrm{RL} 2)_{1}-\beta \mathrm{CD}$ was also maintained after the applied potential was ramped up and down within the range of $\pm 250 \mathrm{mV}$. It might be noted that the binding of neutral molecules such as $\beta \mathrm{CD}$ within the $\alpha \mathrm{HL}$ pore is voltage-dependent, owing to the effects of electrosmosis. ${ }^{17}$ Covalent binding therefore prevents $\beta \mathrm{CD}$ dissociation at potentials where the noncovalent complex is short-lived.

Current-voltage $(I-V)$ curves were measured for $(\mathrm{M} 113 \mathrm{~F})_{6}{ }^{-}$ (M113C-D8RL2) $)_{1}-\beta \mathrm{CD}$ and the noncovalent complex $(\mathrm{M} 113 \mathrm{~F})_{7}{ }^{\circ}$ $\beta \mathrm{CD}$. The $I-V$ curves are not significantly different between +150 and $-60 \mathrm{mV}$. However, when the applied potential is below $-60 \mathrm{mV}$, the $I-V$ curve for $(\mathrm{M} 113 \mathrm{~F})_{6}(\mathrm{M} 113 \mathrm{C}$ D8RL2) $)_{1}-\beta \mathrm{CD}$ is more rectifying than that of $(\mathrm{M} 113 \mathrm{~F})_{7} \cdot \beta \mathrm{CD}$ (Figure 3e).

Electrical Characterization of (M113N $)_{6}($ T117C-D8RL3) . When a single (M113N) $)_{6}(\mathrm{~T} 117 \mathrm{C}-\mathrm{D} 8 \mathrm{RL} 3)_{1}$ protein pore was introduced into the lipid bilayer from the cis chamber, we measured an ionic current of $-80 \pm 5 \mathrm{pA}(-100 \mathrm{mV}, 25 \mathrm{mM}$ Tris $\cdot \mathrm{HCl}, \mathrm{pH} 8.0,1 \mathrm{M} \mathrm{KCl}, n=6)$, which is almost identical to that of the $(\mathrm{WT})_{7}$ pore $(-80 \pm 4 \mathrm{pA}, n=3)$ under the same conditions. After $\beta \mathrm{CD}$-PDP was added to the trans compartment, only one type of transient blocking event was observed with a $70 \%$ current block, which is close to the $65 \%$ block observed with $(\mathrm{M} 113 \mathrm{~N})_{7} \cdot \beta \mathrm{CD}$. After a period ranging from 1 to $20 \mathrm{~min}$, an intermediate state with a lifetime of $5 \pm 2 \mathrm{~ms}(n=$ 5) and $90 \%$ current block was observed, which was followed by a permanent $70 \%$ current block (Figure $4 \mathrm{c}$ ). As in the case of $(\mathrm{M} 113 \mathrm{~F})_{6}(\mathrm{M} 113 \mathrm{C}-\mathrm{D} 8 \mathrm{RL} 2)_{1}-\beta \mathrm{CD}$, this $70 \%$ block was not reversed during a total of $24 \mathrm{~h}$ (over 16 experiments), while the mean $\tau_{\text {off }}$ for $(\mathrm{M} 113 \mathrm{~N})_{7} \cdot \beta \mathrm{CD}$ is only $10.7 \pm 1.5 \mathrm{~s}$ under the same conditions. Again, the applied potential could be ramped up and down within the range of $\pm 250 \mathrm{mV}$ without unblocking the pore. Therefore, this state is presumed to represent the $\alpha \mathrm{HL}$ pore with $\beta \mathrm{CD}$ covalently attached through a disulfide bond to position 117 (Figures 4c, $\mathrm{S} 1 \mathrm{~b})$. Again, the disulfide bond was cleaved after the addition of $2 \mathrm{mM}$ DTT to the cis chamber (Figure 4d). During cleavage, a transient intermediate state with $85 \%$ current block and a lifetime of $300 \pm 20 \mathrm{~ms}(n=5)$ was observed (Figure $4 d)$.

Current-voltage $(I-V)$ curves were measured for the adduct $(\mathrm{M} 113 \mathrm{~N})_{6}(\mathrm{~T} 117 \mathrm{C}-\mathrm{D} 8 \mathrm{RL} 3)_{1}-\beta \mathrm{CD}$ and found to be similar to those of $(\mathrm{M} 113 \mathrm{~N})_{7} \cdot \beta \mathrm{CD}$ within the range of $\pm 100 \mathrm{mV}$, diverging slightly at both high positive and negative potentials (Figure 4e).

Attempts to Link $\beta \mathrm{CD}$ in Unfavored Orientations. To further investigate and confirm the proposed orientation of the covalently attached $\beta \mathrm{CD}$, we prepared the heteroheptamers $(\mathrm{M} 113 \mathrm{~N})_{6}(\mathrm{M} 113 \mathrm{C}-\mathrm{D} 8 \mathrm{RL} 3)_{1}$ and (M113F) $)_{6}(\mathrm{~T} 117 \mathrm{C}-\mathrm{D} 8 \mathrm{RL} 2)_{1}$, in which covalent bond formation between $\beta \mathrm{CD}$-PDP and the protein would in each case produce an orientation of the

(17) Gu, L.-Q.; Cheley, S.; Bayley, H. Proc. Natl. Acad. Sci. U.S.A. 2003, 100, $15498-15503$. cyclodextrin opposite to that which the mutation at position113 normally supports, as evidenced in the X-ray structures (Figure 1).

In the case of (M113N) ${ }_{6}(\mathrm{M} 113 \mathrm{C}-\mathrm{D} 8 \mathrm{RL} 3)_{1}$, covalent attachment of $\beta$ CD-PDP to Cys-113 failed to occur after ten attempts of $30 \mathrm{~min}$ each. By contrast, the heteroheptamer (M113F)6(T117C-D8RL3) ${ }_{1}$ did react with $\beta$ CD-PDP, as indicated by a permanent $80 \%$ current block. Like the two cases described earlier, the attached $\beta \mathrm{CD}$ resisted potential ramps of $\pm 250 \mathrm{mV}$ and could be detached by the addition of $2 \mathrm{mM}$ DTT to the cis chamber (not shown). The presumed covalent adduct, $(\mathrm{M} 113 \mathrm{~F})_{6^{-}}$ (T117C-D8RL3) $1-\beta C D$, was examined by electrical recording in $25 \mathrm{mM}$ Tris $\cdot \mathrm{HCl}, \mathrm{pH} 8.0,1 \mathrm{M} \mathrm{KCl}$, at $\pm 100 \mathrm{mV}(n=3)$. The single-channel current $(24.0 \mathrm{pA},+100 \mathrm{mV})$ was lower than that of (M113N) 6 (T117C-D8RL3) $)_{1}-\beta \mathrm{CD}(40.0 \mathrm{pA},+100 \mathrm{mV})$ and displayed frequent full blockades at both positive and negative potentials (data not shown). In addition, the current passed by (M113F) $)_{6}(\mathrm{~T} 117 \mathrm{C}-\mathrm{D} 8 \mathrm{RL} 3)_{1}-\beta \mathrm{CD}$ was far noisier than that observed with $(\mathrm{M} 113 \mathrm{~N})_{6}(\mathrm{~T} 117 \mathrm{C}-\mathrm{D} 8 \mathrm{RL} 3)_{1}-\beta \mathrm{CD}$, precluding its use for the stochastic sensing of organic analytes (see below).

Analyte Detection Using Engineered $\alpha \mathrm{HL}$ Pores with Covalently Attached $\beta$ CD Adapters. To evaluate the newly created constructs as biosensor detection elements, we carried out stochastic sensing of 2-adamantanamine (2-AdNH $\mathrm{N}_{2}$, a model analyte. ${ }^{12,15}$ The $\beta \mathrm{CD}$ adapter was attached to $(\mathrm{M} 113 \mathrm{~F})_{6}$ $(\mathrm{M} 113 \mathrm{C}-\mathrm{D} 8 \mathrm{RL} 2)_{1}$ or $(\mathrm{M} 113 \mathrm{~N})_{6}(\mathrm{~T} 117 \mathrm{C}-\mathrm{D} 8 \mathrm{RL} 3)_{1}$ in situ as described above. 2-Adamantanamine $\cdot \mathrm{HCl}$ was then added to either the cis or trans chamber and the transient current substates were observed (Figure 5). These events represent the formation and dissociation of individual $2-\mathrm{AdNH}_{2} \cdot \beta \mathrm{CD}$ complexes within the engineered $\alpha \mathrm{HL}$ pore. The mean dwell times $\left(\tau_{\text {off }}\right)$ of $2-\mathrm{AdNH}_{2}$ were similar to those observed when $2-\mathrm{AdNH}_{2}$ was added to the noncovalent complexes $(\mathrm{M} 113 \mathrm{~F})_{7} \cdot \beta \mathrm{CD}$ and $(\mathrm{M} 113 \mathrm{~N})_{7} \cdot \beta \mathrm{CD}$ (Table 1$)$. The small differences in $\tau_{\text {off }}$ probably arise from interference by the linker.

Examination of Long Binding Events Using $\alpha \mathrm{HL}$ Pores with Covalently Attached Adapters. With covalently attached adapters it should be possible to study the kinetics of two types of events that are more difficult to examine with noncovalently attached adapters: long-lived and rare events. cis-Lithocholic acid is the tightest binding molecule known for $\beta \mathrm{CD} .{ }^{18}$ Therefore, we chose it to test the newly constructed pores for studying binding events of long duration. (M113F) $)_{6}(\mathrm{M} 113 \mathrm{C})_{1}-$ $\beta \mathrm{CD}$ was selected because of its quieter background signal in the absence of analyte (see Figure 5, for example). When cislithocholic acid (50 $\mu \mathrm{M}$, Figure 6a) was introduced into the cis chamber in $25 \mathrm{mM}$ Tris $\cdot \mathrm{HCl}, \mathrm{pH} 8.0,1 \mathrm{M} \mathrm{KCl}$, at $+100 \mathrm{mV}$ $(n=3)$, surprisingly, no signal was observed. This is perhaps due to steric hindrance to binding to the cis side of (M113F $)_{6-}^{-}$ (M113C-D8RL2) $)_{1}-\beta \mathrm{CD}$ by the linker that attaches the $\beta \mathrm{CD}$ to the barrel wall. When cis-lithocholic acid $(50 \mu \mathrm{M})$ was introduced into the trans chamber at $-100 \mathrm{mV}(n=3)$, we observed many very long events. The events showed a $98 \%$ current block, with a $92 \%$ block for $200 \pm 100 \mathrm{~ms}$ at the beginning of each event and for $150 \pm 100 \mathrm{~ms}$ at the end of the event (Figure 6b, Figure S3). The mean $\tau_{\text {off }}$ of the events was $8.6 \pm 7.8 \mathrm{~s}$ (number of events $=60$; range $0.5-80 \mathrm{~s}$ ), which is considerably longer than the $\tau_{\text {off }}(0.68 \pm 0.12 \mathrm{~s})$ for

(18) Yang, Z.; Breslow, R. Tetrahedron Lett. 1997, 38, 6171-6172. 


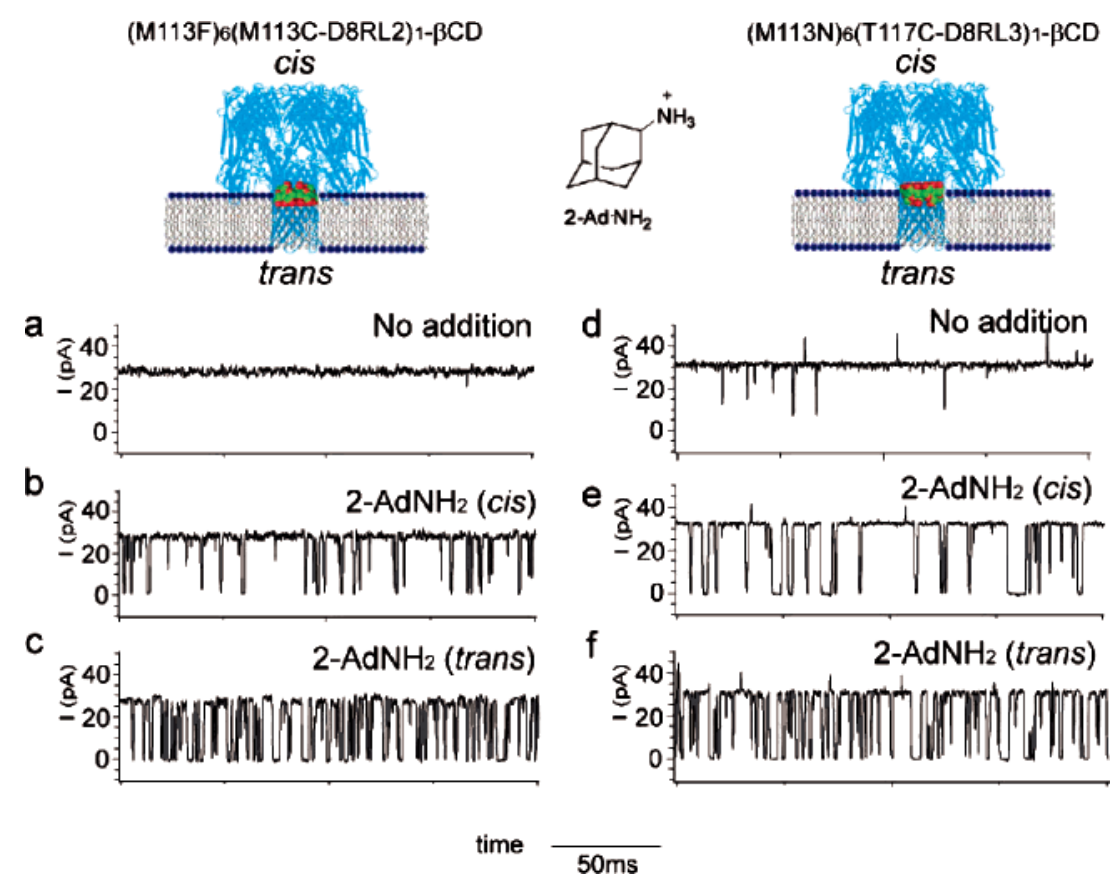

Figure 5. Detection of 2-adamantanamine with $\alpha \mathrm{HL}$ pores containing a covalently attached $\beta \mathrm{CD}$. (a) Current trace from a single (M113F) 6 (M113CD8RL2) $)_{1}-\beta \mathrm{CD}$ pore in $25 \mathrm{mM}$ Tris $\cdot \mathrm{HCl}, \mathrm{pH} 8.0,1 \mathrm{M} \mathrm{KCl}$, at $+100 \mathrm{mV}$. (b) Current trace in the presence of $30 \mu \mathrm{M} 2$-adamantanamine in the cis chamber. (c) Current trace with $30 \mu \mathrm{M} 2$-adamantanamine in the trans chamber. (d) Current trace from a single (M113N) 6 (T117C-D8RL3) $1-\beta C D$ pore in $25 \mathrm{mM}$ Tris $\cdot \mathrm{HCl}, \mathrm{pH} 8.0,1 \mathrm{M} \mathrm{KCl}$, at $+100 \mathrm{mV}$. (e) Current trace with $30 \mu \mathrm{M}$ 2-adamantanamine in the cis chamber. (f) Current trace with $30 \mu \mathrm{M} 2$-adamantanamine in the trans chamber.

Table 1. Stochastic Sensing of 2-Adamantanamine (2-AdNH $\left.{ }_{2}\right)$ with Covalent and Noncovalent Adducts of $\beta \mathrm{CD}$ and $\alpha \mathrm{HL}^{a}$

\begin{tabular}{|c|c|c|}
\hline \multirow[b]{2}{*}{ construct } & \multicolumn{2}{|c|}{$\tau_{\text {off }} \pm \mathrm{SD}(\mathrm{ms})$} \\
\hline & 2-AdNH ${ }_{2}$ (cis) & 2-AdNH ${ }_{2}$ (trans) \\
\hline$(\mathrm{M} 113 \mathrm{~F})_{6}(\mathrm{M} 113 \mathrm{C}-\mathrm{D} 8 \mathrm{RL} 2)_{1}-\beta \mathrm{CD}$ & $\begin{array}{l}0.70 \pm 0.11 \\
(n=7)\end{array}$ & $\begin{array}{l}0.99 \pm 0.05 \\
(n=9)\end{array}$ \\
\hline$(\mathrm{M} 113 \mathrm{~F})_{7} \cdot \beta \mathrm{CD}$ & $\begin{array}{l}1.20 \pm 0.08 \\
(n=6)\end{array}$ & $\begin{array}{l}1.25 \pm 0.07 \\
(n=6)\end{array}$ \\
\hline$(\mathrm{M} 113 \mathrm{~N})_{6}(\mathrm{~T} 117 \mathrm{C}-\mathrm{D} 8 \mathrm{RL} 3)_{1}-\beta \mathrm{CD}$ & $\begin{array}{l}1.15 \pm 0.09 \\
(n=7)\end{array}$ & $\begin{array}{l}1.16 \pm 0.07 \\
(n=9)\end{array}$ \\
\hline$(\mathrm{M} 113 \mathrm{~N})_{7} \cdot \beta \mathrm{CD}$ & $\begin{array}{l}1.12 \pm 0.06 \\
(n=6)\end{array}$ & $\begin{array}{l}1.56 \pm 0.08 \\
(n=8)\end{array}$ \\
\hline
\end{tabular}

${ }^{a}$ Conditions: $25 \mathrm{mM}$ Tris $\cdot \mathrm{HCl}, \mathrm{pH} 8.0,1 \mathrm{M} \mathrm{KCl},+100 \mathrm{mV}$, with 2- $\mathrm{AdNH}_{2} \cdot \mathrm{HCl}$ (cis or trans) at $30 \mu \mathrm{M}$. The number of individual experiments is in parentheses.

$\beta \mathrm{CD}$ in the $(\mathrm{M} 113 \mathrm{~F})_{7} \cdot \beta \mathrm{CD}$ complex under the same conditions, i.e., $\beta \mathrm{CD}$ would most often dissociate from the noncovalent $(\mathrm{M} 113 \mathrm{~F})_{7} \cdot \beta \mathrm{CD}$ during a lithocholic acid binding event. This shows the advantage of the covalently attached adapter over the noncovalent complexes for examining long-lived binding events.

$\alpha H L$ Pores with Covalently Attached Adapters at High Temperatures. We speculated that $\alpha \mathrm{HL}$ pores with covalently attached CDs might work better than underivatized pores at high temperatures when the dwell time of CDs is reduced. ${ }^{15}$ Singlechannel current traces of $(\mathrm{M} 113 \mathrm{~F})_{6}(\mathrm{M} 113 \mathrm{C}-\mathrm{D} 8 \mathrm{RL} 2)_{1}-\beta \mathrm{CD}$ were obtained at up to $55{ }^{\circ} \mathrm{C}$. The single-channel currents depended linearly on the temperature (Figure S4): $I(\mathrm{pA})=$ $14.3+0.54 T\left({ }^{\circ} \mathrm{C}\right)$ in $25 \mathrm{mM}$ Tris $\cdot \mathrm{HCl}, \mathrm{pH} 8.0,1 \mathrm{M} \mathrm{KCl}$ at $+100 \mathrm{mV}$, which is a similar temperature dependence to that observed previously with an $\alpha \mathrm{HL}$ pore with noncovalently bound $\beta \mathrm{CD} .{ }^{15}$ No dissociation of $\beta \mathrm{CD}$ from the $(\mathrm{M} 113 \mathrm{~F})_{6}$ $(\mathrm{M} 113 \mathrm{C}-\mathrm{D} 8 \mathrm{RL} 2)_{1}-\beta \mathrm{CD}$ pore was observed during these experiments. For example, the current passed by (M113F)6(M113CD8RL2) $)_{1}-\beta \mathrm{CD}$ remained constant at $55{ }^{\circ} \mathrm{C}$ during a $5 \mathrm{~min}$ measurement, while the $\tau_{\text {off }}$ for $\beta \mathrm{CD}$ noncovalently bound to $(\mathrm{M} 113 \mathrm{~F})_{6}(\mathrm{M} 113 \mathrm{C}-\mathrm{D} 8 \mathrm{RL} 2)_{1}$ was only $56 \pm 3.8 \mathrm{~ms}$ under the same conditions. These data show that $\alpha \mathrm{HL}$ pores with covalently attached CDs permit stochastic sensing in aqueous solution under extreme conditions.

Permanent Alteration of Ion Selectivity in $\alpha$ HL Pores with Covalently Attached Adapters. Noncovalent molecular adapters lodged within the $\alpha \mathrm{HL}$ pore can alter the charge selectivity for ion transport. ${ }^{19}$ For example, at $\mathrm{pH} 7.5$, the charge selectivity $\left(P_{\mathrm{K}^{+}} / P_{\mathrm{Cl}^{-}}, \mathrm{KCl}\right.$ : cis $200 \mathrm{mM}$, trans $\left.1000 \mathrm{mM}\right)$ of WT- $\alpha \mathrm{HL}$ changes from $0.55 \pm 0.02$ to $0.25 \pm 0.01$ after $\beta \mathrm{CD}$ becomes lodged in the lumen, i.e., the pore becomes more anion selective. ${ }^{19}$ Therefore, we expected that $\beta \mathrm{CD}$, covalently attached inside the $\beta$ barrel, would alter the ion selectivity of an $\alpha$ HL pore permanently. We took (M113F) ${ }_{6}(\mathrm{M} 113 \mathrm{C}-\mathrm{D} 8 \mathrm{RL} 2)_{1}$ and $(\mathrm{M} 113 \mathrm{~F})_{6}(\mathrm{M} 113 \mathrm{C}-\mathrm{D} 8 \mathrm{RL} 2)_{1}-\beta \mathrm{CD}$ as a test case and constructed $I-V$ curves for single-channel currents recorded under both cis/trans and trans/cis $\mathrm{KCl}$ gradients (Figure S5). The measured conductance values $(g)$ and reversal potentials $\left(V_{\mathrm{r}}\right)$, and the charge selectivity $\left(P_{\mathrm{K}^{+}} / P_{\mathrm{Cl}^{-}}\right)$calculated from the Goldman-Hodgkin-Katz equation, ${ }^{20}$ of both the underivatized and derivatized pores are shown in Table 2 . The covalently attached molecular adapter indeed altered the charge selectivity of the $\alpha \mathrm{HL}$ pore and this effect was permanent. Again, the pore becomes more anion selective and the observed changes in $P_{\mathrm{K}^{+}} /$ $P_{\mathrm{Cl}^{-}}$are similar to those seen with noncovalently bound $\beta \mathrm{CD} .{ }^{19}$ This feature should be useful in the de novo design of membrane channels both for basic studies of ion permeation and for applications in biotechnology, where a varied assemblage of pores with modified properties would be of great utility. ${ }^{21,22}$

(19) Gu, L.-Q.; Dalla Serra, M.; Vincent, J. B.; Vigh, G.; Cheley, S.; Braha, O.; Bayley, H. Proc. Natl. Acad. Sci. U.S.A. 2000, 97, 3959-3964.

(20) Hille, B. Ion channels of excitable membranes, 3rd ed.; Sinauer: Sunderland, MA, 2001. 
a

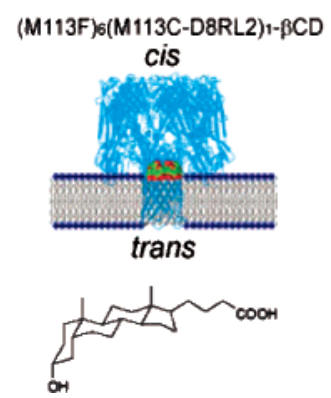

b

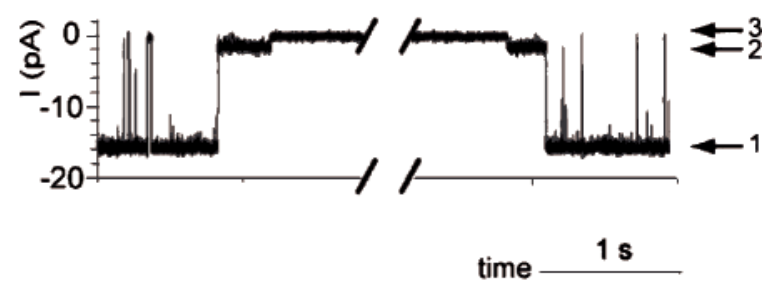

Figure 6. Long binding events of $c i s$-lithocholic acid with (M113F) 6 (M113C-D8RL2) ${ }_{1}-\beta C D$. (a) $\alpha$ HL with attached molecular adapter (M113F) 6 (M113CD8RL2) $)_{1}-\beta C D$ and the structure of $c i s$-lithocholic acid. (b) Characteristic binding event of $c i s$-lithocholic acid (50 $\left.\mu \mathrm{M}\right)$ with (M113F) 6 (M113C-D8RL2) $1-$ $\beta \mathrm{CD}$ in $25 \mathrm{mM}$ Tris $\cdot \mathrm{HCl}, \mathrm{pH} 8.0,1 \mathrm{M} \mathrm{KCl}$, at $-100 \mathrm{mV}$. Mean $\tau_{\text {off }}=8.6 \pm 7.8 \mathrm{~s}$ (number of events $\left.=60\right)$. Level 1, $(\mathrm{M} 113 \mathrm{~F})_{6}(\mathrm{M} 113 \mathrm{C}-\mathrm{D} 8 \mathrm{RL} 2)_{1}-\beta \mathrm{CD}$;

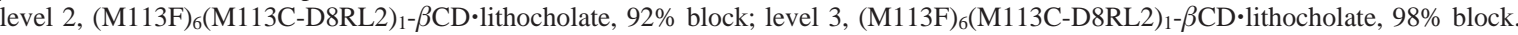

Table 2. Reversal Potentials $\left(V_{\mathrm{r}}\right)$, Calculated Charge Selectivities $\left(P_{\mathrm{K}^{+}} / P_{\mathrm{Cl}^{-}}\right)$and Conductance Values $(g)$ of $(\mathrm{M} 113 \mathrm{~F})_{6}(\mathrm{M} 113 \mathrm{C}-\mathrm{D} 8 \mathrm{RL} 2)_{1}$ and $(\mathrm{M} 113 \mathrm{~F})_{6}(\mathrm{M} 113 \mathrm{C}-\mathrm{D} 8 \mathrm{RL} 2)_{1}-\beta \mathrm{CD}$

\begin{tabular}{|c|c|c|c|c|}
\hline pore & buffer $^{b}$ & $V_{r}(\mathrm{mV})$ & $P_{\mathrm{K}^{+}} / P_{\mathrm{C} \Gamma}$ & $g(\mathrm{pS})^{\mathrm{c}}$ \\
\hline$(\mathrm{M} 113 \mathrm{~F})_{6}(\mathrm{M} 113 \mathrm{C}-\mathrm{D} 8 \mathrm{RL} 2)_{1}$ & $\begin{array}{l}\text { cis } 200 / \text { trans } 1000 \\
\text { cis } 1000 / \text { trans } 200\end{array}$ & $\begin{array}{r}11.4 \pm 0.1 \\
-5.0 \pm 0.1\end{array}$ & $\begin{array}{l}0.47 \pm 0.01 \\
0.73 \pm 0.02\end{array}$ & $973 \pm 10$ \\
\hline$(\mathrm{M} 113 \mathrm{~F})_{6}(\mathrm{M} 113 \mathrm{C}-\mathrm{D} 8 \mathrm{RL} 2)_{1}-\beta \mathrm{CD}$ & $\begin{array}{l}\text { cis } 200 / \text { trans } 1000 \\
\text { cis } 1000 / \text { trans } 200\end{array}$ & $\begin{array}{r}28.3 \pm 0.2 \\
-26.0 \pm 0.2\end{array}$ & $\begin{array}{l}0.10 \pm 0.01 \\
0.14 \pm 0.01\end{array}$ & $295 \pm 5$ \\
\hline
\end{tabular}

${ }^{a}$ For each entry, three separate experiments were performed. The reversal potentials $\left(V_{\mathrm{r}}\right)$ are mean values $(n=3)$ under the conditions stated. Charge selectivities $\left(P_{\mathrm{K}^{+}} / P_{\mathrm{Cl}^{-}}, n=3\right)$ and conductance values $(n=3)$ are quoted as the mean $\pm \mathrm{SD}$. $P_{\mathrm{K}^{+}} / P_{\mathrm{Cl}^{-}}$was calculated with the Goldman-Hodgkin-Katz equation by using activities and the experimental $V_{\mathrm{r}}$ value. ${ }^{20} \quad b 25 \mathrm{mM}$ Tris $\cdot \mathrm{HCl}, \mathrm{pH} 8.0$. The salt concentrations $(\mathrm{KCl})$ are given in $\mathrm{mM} .{ }^{c}+100 \mathrm{mV}, 1 \mathrm{M}$ $\mathrm{KCl}, 25 \mathrm{mM}$ Tris $\cdot \mathrm{HCl}$, $\mathrm{pH} 8.0$, in both chambers.

Summary and Prospects. Engineering of the $\alpha \mathrm{HL}$ pore to allow the binding of organic analytes for stochastic detection has been successful only rarely, ${ }^{7}$ but noncovalent molecular adapters have proved useful in this regard, despite certain limitations imposed by their continual association with and dissociation from the pore. To remedy the latter problem, we have now covalently attached the $\beta \mathrm{CD}$ adapter inside the $\alpha \mathrm{HL}$ pore. Further, the attachment has been performed with control over the orientation of the $\beta \mathrm{CD}$, i.e., with the primary hydroxyls of the $\beta \mathrm{CD}$ facing either the trans or the cis entrance of the pore. Covalent attachment means that there are no gaps in detection, and control over the $\beta \mathrm{CD}$ orientation is important because it is likely that certain analytes bind through only one of the two entrances to the $\beta \mathrm{CD}$ cavity or that they bind in different ways depending upon the side of entry. ${ }^{9}$ To exemplify the utility of $\alpha \mathrm{HL}$ pores with covalently attached $\beta \mathrm{CD}$ in stochastic sensing, we show here that the pores can be used to detect analytes with long dwell times within $\beta C D$. In this case, the $\beta \mathrm{CD}$ would normally dissociate from the pore before the analyte dissociates from the $\beta \mathrm{CD}$, degrading the information content of the signal. ${ }^{8}$ The effects of continual CD association and dissociation are exacerbated at high temperatures, ${ }^{15}$ and as demonstrated here, covalent attachment also remedies this problem. We also show that $\alpha \mathrm{HL}$ pores with covalently attached $\beta \mathrm{CD}$ can have permanently altered ion selectivity, which might be useful, for example, for building nanobatteries. ${ }^{21,22}$

Single-molecule DNA sequencing, ${ }^{23}$ a more futuristic endeavor, might also benefit from the use of protein nanopores containing covalently attached $\beta$ CDs. In one approach, deoxyribonucleoside $5^{\prime}$-monophosphates are released from an indi-

(21) Hwang, W. L.; Holden, M. A.; White, S.; Bayley, H. J. Am. Chem. Soc. 2007, 129, 11854-11864.

(22) Holden, M. A.; Needham, D.; Bayley, H. J. Am. Chem. Soc. 2007, 129, $8650-8655$.

(23) Bayley, H. Curr. Opin. Chem. Biol. 2006, 10, 628-637. vidual DNA strand by a processive exonuclease. ${ }^{24}$ In the original manifestation, which has proved very difficult to implement, fluorescent base analogues would be released from a fully substituted transcribed DNA strand. However, we have recently shown that the four deoxyribonucleoside $5^{\prime}$-monophosphates can be distinguished by using the noncovalent $\alpha \mathrm{HL}(\mathrm{M} 113 \mathrm{R})_{7}{ }^{\circ}$ $\operatorname{am}_{7} \beta \mathrm{CD}$ complex, where $\mathrm{am}_{7} \beta \mathrm{CD}$ is heptakis-(6-deoxy-6amino)- $\beta$-cyclodextrin. ${ }^{11}$ While this is a step forward, for successful sequencing, every base released by an exonuclease must be captured by the detection element and identified. Therefore, if the $\alpha \mathrm{HL}$ pore with a molecular adapter is to be used, the adapter must be covalently attached to avoid gaps in sequencing.

\section{Materials and Methods}

$\alpha$ HL Pores. The $\alpha$-hemolysin mutant pores (M113F) $)_{7}$ (WT background), (M113N) 7 (WT background), (M113F) 6 (M113C-D8RL2) 1 , and (M113N) 6 (T117C-D8RL3) 1 were expressed, assembled, and purified as previously described. RL2 is the product of a semisynthetic gene that was devised to permit cassette mutagenesis of the sequence encoding the transmembrane $\beta$ barrel. ${ }^{25}$ It contains six silent restriction sites and four altered amino acids in the encoded polypeptide sequence. RL3 is identical to the WT $\alpha \mathrm{HL}$ polypeptide at the amino acid level, but the gene contains six silent mutations in the region encoding the $\beta$ barrel that aid cassette mutagenesis (S. Cheley, unpublished). To prepare the heteroheptamers, a C-terminal tail of eight aspartate residues was encoded in the genes of M113C-D8RL2 and T117C-D8RL3. This aspartate tail allowed the resolution of heptamers with different combinations of subunits by SDS-polyacrylamide gel electrophoresis. ${ }^{26}$

Chemicals. Reagents were obtained as follows. 1,2-Diphytanoyl$s n$-glycero-3-phosphocholine (Avanti Polar Lipids), pentane (JT Baker),

(24) Jett, J. H.; Keller, R. A.; Martin, J. C.; Marrone, B. L.; Moyzis, R. K.; Ratliff, R. L.; Seitzinger, N. K.; Shera, E. B.; Stewart, C. C. J. Biomol. Struct. Dynam. 1989, 7, 301-309.

(25) Cheley, S.; Braha, O.; Lu, X.; Conlan, S.; Bayley, H. Protein Sci. 1999, 8, 1257-1267.

(26) Howorka, S.; Cheley, S.; Bayley, H. Nat. Biotechnol. 2001, 19, 636-639. 
hexadecane (99+\%, Sigma-Aldrich), 6-monodeoxy-6-monoamino- $\beta$ cyclodextrin hydrochloride (99\%, Cyclolabs Budapest, Hungary), Trizma base $(99.9 \%$, Sigma-Aldrich), concentrated $\mathrm{HCl}$ (analytical reagent grade, Fisher Scientific), potassium chloride (99\%, SigmaAldrich), 2-adamantanamine $\cdot \mathrm{HCl}$ (99\%, Aldrich), succinimidyl 3-(2pyridyldithio)propionate (SPDP, 95\%, Fluka), triethylamine $(99.5 \%$, Fluka).

Synthesis of $\beta$ CD-PDP. 6-Monodeoxy-6-monoamino- $\beta$-cyclodextrin $\left(\mathrm{am}_{1} \beta \mathrm{CD}\right)$ hydrochloride $(11.7 \mathrm{mg}, 0.01 \mathrm{mmol})$ and succinimidyl 3-(2pyridyldithio)propionate (SPDP, $6.24 \mathrm{mg}, 0.02 \mathrm{mmol}$ ) were dissolved in $5 \mathrm{~mL}$ of $\mathrm{MeOH} / \mathrm{H}_{2} \mathrm{O}(1: 1)$. Triethylamine $(100 \mu \mathrm{L})$ was added over $5 \mathrm{~min}$, and the mixture was stirred overnight. The desired product appeared as a white precipitate, which was filtered off and washed successively with cold water and acetone. An analytical sample was obtained by recrystallization from DMSO and water. ${ }^{1} \mathrm{H}$ NMR (DMSO$\left.d_{6}\right): \delta 8.61(\mathrm{~m}, 1 \mathrm{H}), 7.82(\mathrm{~m}, 2 \mathrm{H}), 7.25(\mathrm{ddd}, J 7.2,4.8,1.2 \mathrm{~Hz}, 1 \mathrm{H})$, $5.75(\mathrm{~m}, 14 \mathrm{H}), 4.83(\mathrm{~m}, 7 \mathrm{H}), 4.67(\mathrm{~m}, 7 \mathrm{H}), 3.64(\mathrm{~m}, 35 \mathrm{H}), 2.99(\mathrm{t}, J$ $7.2 \mathrm{~Hz}, 2 \mathrm{H}), 2.55$ (t, $J 7.2 \mathrm{~Hz}, 2 \mathrm{H}$ ). ESI-MS [M $+\mathrm{Na}]^{+} 1353.37$; theoretical distribution 1353.37, 100\%; 1354.38, 52.3\%; 1355.38, $26.3 \% ; 1356.38,8.7 \%, 1357.38,2.7 \% ; 1358.38,0.8 \%$. Found 1353.37 , $100 \%$; $1354.38,58.6 \%, 1355.37,33.1 \%, 1356.38,12.6 \%, 1357.38$, $4.3 \%, 1358.38,1.2 \%$.

Single-Channel Current Recording. A bilayer of 1,2-diphytanoyl$s n$-glycero-3-phosphocholine (Avanti Polar Lipids) was formed across an aperture $100-150 \mu \mathrm{m}$ in diameter in a polycarbonate film $(20-\mu \mathrm{m}$ thickness from Goodfellow, Malvern, PA) that divided a planar bilayer chamber into two compartments, cis and trans. Both compartments contained $1 \mathrm{~mL}$ of buffer. Engineered protein pores were added to the cis compartment, which was connected to ground. $\beta$ CD-PDP was added to the trans compartment, which was connected to the head-stage of the amplifier. All experiments were carried out at $\pm 100 \mathrm{mV}$ in $25 \mathrm{mM}$
Tris $\cdot \mathrm{HCl}, 1 \mathrm{M} \mathrm{KCl}, \mathrm{pH} 8.0$, at $22.5 \pm 2{ }^{\circ} \mathrm{C}$, unless otherwise stated. Fresh frozen aliquots of protein and $\beta$ CD-PDP were used each day. Currents were recorded with a patch clamp amplifier (Axopatch 200B; Axon instruments, Foster City, CA), low-pass filtered with a built-in four-pole Bessel filter at $10 \mathrm{kHz}$, and sampled at $20 \mathrm{kHz}$ by a computer equipped with a Digidata 1200 A/D converter (Axon instruments).

Data Analysis. Current traces were analyzed with pClamp 9.0 software (Axon Instruments). Events were detected using the Event Detection feature, and used to construct amplitude and dwell time histograms. Origin (Microcal, Northampton, MA) was used for curve fitting and graph presentation.

Molecular Models. The pdb files of the heptameric $\alpha$-hemolysin pores complexed with $\beta \mathrm{CD},(\mathrm{M} 113 \mathrm{~F})_{7} \cdot \beta \mathrm{CD}$, and $(\mathrm{M} 113 \mathrm{~N})_{7} \cdot \beta \mathrm{CD}$, provided by Michelle Montoya and Eric Gouaux, were displayed in PyMOL (DeLano Scientific, San Carlos, CA). The $\beta$ CD-PDP structure was also constructed in PyMOL by using the building tools.

Acknowledgment. This work was supported by the NIH, the MRC, and a U.K. Research Councils Bionanotechnology IRC. H.B. is the holder of a Royal Society-Wolfson Research Merit Award. We thank Dr. E. Gouaux and Dr. M Montoya for the $\mathrm{X}$-ray structures of $(\mathrm{M} 113 \mathrm{~F})_{7} \cdot \beta \mathrm{CD}$ and $(\mathrm{M} 113 \mathrm{~N})_{7} \cdot \beta \mathrm{CD}$, Dr. Stephen Cheley for the plasmid pT7-RL3, and Dr. O. Braha and $\mathrm{S}$. Lu for valuable assistance.

Supporting Information Available: Additional figures, as described in the text. This material is available free of charge via the Internet at http://pubs.acs.org.

JA0761840 